\title{
Akademide zaman yönetimi tutumlarında cinsiyetin faktörü: Bir vakıf üniversitesinde araştırma
}

\section{The factor of gender in the attitudes of time management at the academy: Research in a foundation university}

\author{
Hamide Selçuk ${ }^{1}$ (D) Ahmet Akar ${ }^{2}$ (D) \\ 1 Arş. Gör., KTO Karatay Üniversitesi, İşletme Bölümü, Konya, Türkiye, e-mail: hamide.selcuk@karatay.edu.tr \\ 2 Proje. Asist., KTO Karatay Üniversitesi, İşletme Bölümü, Konya, Türkiye, e-mail: ahmet.akar@karatay.edu.tr
}

Öz

Bu araştırmada temel amaç; akademide zaman yönetimi tutumlarının cinsiyete göre bir farklılık gösterip göstermediği sorusuna cevap bulmaktır. Araştırmanın evrenini bir vakıf üniversitesinde çalışan 90 araştırma görevlisi oluşturmaktadır. Veriler hazırlanan anket formu ile toplanmıştır. Anket formunun birinci kısmında "5" soruluk demografik bilgi formu, ikinci kısmında ise Ardıç (2010) tarafından yüksek lisans tezinde kullanılan iki alt boyuttan oluşan "Zaman Yönetimi" ölçeği kullanılmıştır. Toplanan veriler ile "SPSS for Window 23,0" programı kullanılarak "Mann Whitney U” ve "Kruskall Walliss $\mathrm{H}^{\prime \prime}$ analizleri yapılmıştır. Sonuçlara göre zaman tuzakları alt boyutunda cinsiyete göre anlamlı bir farklılık görülmezken, zamanı etkin kullanma yöntemleri boyutunda cinsiyete göre anlamlı bir farklılık görülmektedir. Araştırma sonucunda kadınların zamanı etkin kullanma düzeylerinin, erkeklere göre daha yüksek olduğu tespit edilmiştir.

Anahtar kelimeler: Zaman, zaman yönetimi, cinsiyet

JEL kodları: M10, M19

\begin{abstract}
The main purpose of this research is; To answer the question of whether time management attitudes differ by gender. The universe of the research consists of 90 research assistants working at a foundation university. The data were collected with the prepared questionnaire form. In the first part of the questionnaire form, a demographic information form with "5" questions was used, in the second part, "Time Management" scale, consisting of two sub-dimensions, used by Ardiç (2010) in his master's thesis was used. By using "SPSS Window 23.0" programme, "Mann Whitneyy U" and "Kruskall Walliss $\mathrm{H}^{\prime \prime}$ analyzes were performed. According to the results, while no significant difference was seen in the time traps sub-dimension by gender, there was a significant difference in terms of gender in the dimension of effective use of time. As a result of the research, it has been determined that the effective use of time of women is higher than men.
\end{abstract}

Keywords: Time, time management, gender

JEL codes: M10, M19

Citation/Atıf: SELÇUK, H. \& AKAR, A., (2021). Akademide zaman yönetimi tutumlarında cinsiyetin faktörü: Bir vakıf üniversitesinde araştırma. Journal of Life Economics. 8(4): 523-532, DOI: $10.15637 /$ jlecon.8.4.11

Corresponding Author/ Sorumlu Yazar: Ahmet Akar

E-mail: ahmet.akar@karatay.edu.t
Bu derginin içeriği Creative Commons Attribution-NonCommercial 4.0 Uluslararası Lisansı altında lisanslanmıştır.

Content of this journal is licensed under a Creative Common Attribution-NonCommercial 4.0 International License. 


\section{GİRIŞ}

Zaman kelime anlamıyla, geçmiş zamandan geleceğe doğru sıralı olayların süregeldiği ve kişilerin müdahalesi olmaksızın ilerleyen bir süreci ifade etmektedir (H. Smith, 1998, p. 25). Ve bu süreç insanlığın doğuşundan bugüne kadar uzanan ve durmadan değer kazanan bir yapıya sahiptir (Çimen, 2017, p. 112). Özellikle rekabetin yoğunluğunun ve baskısının arttığ1 son yıllarda, şahıslar veya işletmeler fark etmeksizin herkesçe eşit paylaşılan zaman kaynağının ne kadar değerli olduğu, nasıl harcanılması gerektiği idrak edilmeli ve harcanan zaman kontrol edilmelidir. Çünkü zaman asla ikame edilemeyecek, para ile satın alınamayacak bir kaynaktır. İnsanlar da şahsi hayatlarında ya da iş hayatlarında zamanı yakalamak için yoğun şekilde uğraşır hale gelmiştir (Erdem vd., 2005, p. 167). Araştırmacıların da ilgisini çeken "zaman" yapılan araştırmalar sonucunda insanların verimliliği üzerinde etkin olduğunu göstermiş ve bu noktada "zaman yönetimi" kavramı devreye girmiştir (Tektaş ve Tektaş, 2010, p. 222).

Zaman yönetimi; tespit edilen ihtiyaçları gidermek adına gerekli hedefleri belirlemek, bu hedefler arasından ise öncelikli olanları tespit ederek zamanı, "planlama, programlama ve listeleme" yolu ile uygun hale getirmektir. Yani zamanı yönetmek "amaç ve hedeflere" varmak için önemli olan zaman kaynağını "etkin ve verimli" bir şekilde kullanma gayretidir (Kibar vd., 2014, p. 137). Zaman yönetimi sadece kişiler açısından değil, işletmeler açısından da çok önemli bir kaynaktır. Çünkü işletmelerin rakiplerine karşı üstün olmaları ve işletmenin devamlılığını sağlamaları açısından öğrenilmesi ve doğru şekilde uygulanması gereken yeni bir stratejidir. Farklılık oluşturmanın ve rekabet ortamına ayak uydurabilmenin şartı zaman kaynağını en etkin biçimde kullanarak maksimum faydayı elde etmekten geçmektedir (Akyüz vd., 2015, p. 93). Çalışanların zamanı yöneterek etkin ve verimli kullanması doğrudan işletmenin performansını etkilemektedir. $\mathrm{Bu}$ noktada zaman yönetiminin temel amacı kısıtlı olan zamanı artırmaya çabalamak yerine, kısıtlı zaman diliminde yürütülecek eylemlerin niteliğini artırmak olmalıdır (Erdem vd., 2005, p. 167).

Zaman yönetimi kavramı çalışmalarda sıklıkla yer bulmasına rağmen yapılan çalışmalar incelendiğinde cinsiyet faktörüne doğrudan değinen bir çalışmaya rastlanılmamıştır. Bu doğrultuda ilgili yazına katkıda bulunacağı düşünülerek zaman yönetiminde cinsiyet algısının tespit edilmesi çalışmanın amacı olarak belirlenmiştir.

\section{KAVRAMSAL ÇERÇEVE}

\subsection{Zaman}

Zaman, insanların sonsuzluğu ve dünyayı daha an- laşılır kılmak adına ortaya çıkardıkları bir kavramdır (Greene vd., 2004, p. 410). Ama bu kavram oldukça zorludur. Yıllardan beri birçok şaire konu olmuş, bilim insanlarının, düşünürlerin üzerinde durduğu bir kavram olmuştur (Kibar vd., 2014, p. 137). Buna rağmen zaman anlamca muğlaktır. Yani zamanı ifade edecek herkes tarafından kabul gören bir tanımı bulunmamaktadır. Zaman net olarak ölçülemeyen, soyut bir ifadedir ve bir ölçü aracı olarak, "uzağın, yakının, geçmişin ve geleceğin" anlamlarını içinde barındırır. "Dün, bugün ve yarın" ifadeleri ile de belirli bir süre anlatılmaktadır (Öktem, 1993, p. 218). Smith (1998)'e göre zaman kavramı, geçmiş zamandan geleceğe doğru sıralı olayların süregeldiği ve kişilerin müdahalesi olmaksızın ilerleyen bir süreçtir. TDK Büyük Türkçe Sözlüğü 'ne göre zaman; “Bir işin, bir oluşun içinde geçtiği, geçeceği veya geçmekte olduğu süre, vakit" olarak ifade edilmektedir. Zaman geçmişten geleceğe doğru ilerleyen olayların izlediği kesintisiz süreçtir. Yani zaman harekete anlam kazandıran ana unsurdur. Anlık olarak dünyada hareketli olan her şey hareketsiz kaldığ 1 düşünüldüğünde hareketsiz bir ortamda zaman kavramindan bahsedilememektedir. (Akatay, 2003, p. 282; M. Gürbüz ve Aydın, 2012). Bir başka tanıma göre zaman doğrusallığı değil varoluşu ifade etmektedir. Nicelikten ziyade niteliği önemlidir. Yani harcanılan zaman önemli değildir önemli olan geçen sürede elde edilen değer ve kalitesidir (Sezen, 2013). Zaman aslında aykırılık gösteren bir kavramdır. Bir yandan kişinin geleceğe yön verebilmesi için yeterli bir zamanı yokken, diğer yandan ise kişi bütün zamanın sahibidir (Silahtaroğlu, 2004, p. 4). Tüm bunlar ışığında zaman bir süreç şeklinde hayatın sürdürülmesinde, bir kuruluşun ömrünün tayin edilmesinde bir "fırsat ve mühlet" olarak düşünülmektedir (Ören, 2016, p. 189).

Günümüzün en önemli kaynağı zamandır. Çünkü zaman, insanlara verilen sürenin bütünüdür, her insanın kullanabileceği sınırlı bir zamanı vardır ve asla bitmezmiş gibi görünmesine rağmen zaman sonsuz bir kaynak değildir, telafisi yoktur. Fakat buna rağmen insanlar tarafından sıkça geri plana itilmektedir (Kibar, 2014, p. 137; Örücü vd., 2007, p. 9).

Zaman kavramı ortamlara ve varlıklara göre farklı anlamlar kazanmaktadır. Zaman çeşitleri “objektif, sübjektif, biyolojik, örgütsel, yönetsel, iktisadi ve sosyolojik zaman" olmak üzere yedi başlıkta incelenmektedir. Objektif zaman; ölçülebilen, kaynağını dünyanın güneş etrafındaki dönüşünden alan ve her birey için aynı olarak tanımlanmış zamandır. Sübjektif zaman; "hissedilen veya algılanan zaman" yani kişilere göre değişkenlik gösteren zamandır. Biyolojik zaman; kişilerin varoluşlarından itibaren sahip oldukları özelliklerinden dolayı içsel dengelerini oluşturan doğal ritme denilmektedir. Örneğin bitkiler biyolojik zaman göre yaşamaktadırlar. Günün ağarmasıyla bazı çiçek- 
ler açarken, bazıları kapanır, bazıları ise güneşe döner. $\mathrm{Bu}$ durum biyolojik zaman olarak ifade edilmektedir. Örgütsel zaman; “örgütlerin belirlemiş olduğu amaç ve hedeflere ulaşabilmesi için mal ve hizmet üretebilmesi için, belirtili bir süre içinde yerine getirilmesi gereken işlevlere, iş gören ve makine tarafından harcanan sürelerin toplamıdır." Yönetsel zaman; çok sayıda kişiyi bir araya getirmek adına oluşturulan amaç ve bu amaca erişmek adına yönetim fonksiyonlarının uygulanmasına adına yöneticilerin harcadıkları zamanı ifade etmektedir. İktisadi zaman; örneğin harcanan emeğin karşılığında verilen ücretin sıklıkla "saat, gün, hafta ve ay" olarak hesaplanmasıdır. Son olarak ise sosyolojik açıdan zaman kişilerin bayram, tören gibi takvimlere bağlı kalarak yapmış oldukları faaliyetleri ifade etmektedir (Albayati, 2018, p. 7; Ardıç, 2010, p. 54; Çelik vd., 2016, p. 9).

Zaman bir ölçü birimi olmanın yanında aynı zamanda ekonomik bir değeri ifade eder. Yani zaman para olarak değerlendirilir ama parayı zaman olarak değerlendirmek mümkün değildir. Çünkü para tekrar kazanılabilir ama zamanı kazanmak mümkün değildir (Ulusoy, 1995, p. 12). İşletmeler maddi ya da beşerî sermaye yönünden güçlü olabilir ve bu sayede ortaya koyduğu stratejileri kolayca uygulayabilirler. Fakat işletmeler asla "zaman zengini" olamazlar (Örücü vd., 2007, p. 10). Ekonomi uzmanları ve yöneticiler de zamanı kıt bir kaynak olarak ifade etmektedirler. Ekonomi kitaplarında zamanın önemini anlatan "dün iptal edilmiş bir çektir", "yarın, bir borç senedidir", "bugün nakit paradır" deyimleri kullanılmaktadır (Özer, 2012, p. 48). Yerinde ve etkin şekilde kullanılmayan zaman beşerî ve insan kaynaklarının verimli olmasına engel olan bir unsur şeklini almaktadır. Yanlış düzenlenen zaman yarar sağlamaktan ziyade kişisel ve kurumsal açıdan zararlı bir yapı haline gelecektir (Ören, 2016, p. 189). Bu yüzden işletmeler insan gücü, makine-teçhizat ve malzemenin yanında zamanı da planlamalı, üretim giderleri olarak değerlendirmeli ve boşa harcamadan verimli ve etkin bir şekilde kullanmalıdır (Ulusoy, 1995, p. 12).

Akan zamanı fark etmek ile zamanın nasıl geçtiğini fark etmek aynı değildir. Her insan saatlerin, gecenin ya da gündüzün nasıl geçtiğinin farkındadır, fakat akan zamanın farkında olmak ona anlam yüklemek ile mümkündür (Türkel ve Leblebici, 2000, p. 360). Sonuç itibari ile gelişmek ve kazanmak için ilk olarak zamana hâkim olunmalıdır. Çok kıymetli olan bu sermayenin bir salisesi dahi boşa verilmemeli ve en doğru şekilde kullanılmalıdır (Tengilimoğlu ve Bektaş, 2012).

\subsection{Zaman Yönetimi}

Zaman, hangi meslekte çalıştığı önemli olmaksızın kişiler üzerinde baskı uygulayan evrensel özelliği olan bir kaynaktır. Zaman yönetimi ise bu baskıyı azaltmak için kişinin planlarını gündelik hayata aktararak sırasıyla uygulamasıdır (Güçlü, 2001, p. 88). Yani zaman yönetimi belirlenen faaliyetlerin önem sırasının yapılarak mevcut zaman içerisine etkin olacak şekilde yerleştirilmesidir (Silahtaroğlu, 2004, p. 4). Claessens vd. (2007)' e göre zaman yönetimi, “hedefe yönelik faaliyetler gerçekleştirilirken zamanın etkili bir şekilde kullanılmasını amaçlayan davranışlar" olarak ifade edilmektedir. Bu kavram iş yükü fazla olan yöneticilerin zamanlarını daha etkin şekilde düzenleyebilmek adına Danimarka'da bir eğitim aracı olarak gün yüzüne çıkmış ve dünya geneline dağılan bir kavram olmuştur. 80'li dönemlerin ortalarında ise Türkiye'de önemi hissedilmiştir. Özellikle günümüzde kişilerin ortak sorunu haline gelen zaman yönetimi başta profesyonel iş hayatında olan bireyler olmak üzere insanların kıt zaman zarfında birden fazla işi yapmasını gerekli kılmıştır (Döner, 2016, p. 9).

Zaman, insanlar tarafından yönetilmesi ve kontrolü mümkün olmayan bir kavramdır. Fakat insanlar kendilerini ve zamanlarını kullanmayı yönetebilirler. Yani zaman yönetimi özünde kişinin kendisini yönetmesi, yaşantısındaki olayları kontrol etmesi sürecidir (Kıdak, 2011, p. 162). Zamanın daha verimli bir biçimde yönetilebileceği, değerli ve kıt bir kaynak olduğunun bilinciyle hareket edilmesi gerekmektedir. Zamana karşı duyarlı olunmazsa ihtiyaç duyulduğunda bulunamayacaktır ve zamanın kaybı asla telafi edilemeyecektir (Koch, 2011, p. 161). Ayrıca zaman doğru yönetilemediği takdirde kişide strese neden olmaktadır. Zamanı olmadığından yakınan insanlar genelde zamanı kullanmayı beceremeyenlerdir. Zamanını kontrol altında tutamayan kişinin, yaşantısını kontrol altında tutması mümkün değildir (Eriş vd., 2017).

İşletmeler açısından bakıldığında planlama, yönetim, koordinasyon ve denetleme gibi ana unsurlarda zaman oldukça etkilidir ve bu yüzden işletmenin hedeflerine ulaşmasında oldukça önemli bir kaynaktır. Ayrıca işletmeler herkesin aynı oranda sahip olduğu zaman kaynağını hem etkin hem de verimli şekilde kullanarak farklarını ortaya koymalıdır. Sadece zamanın önemini ve yönetilmesi gerektiğini kavrayan ve uygulamaya koyan işletmeler hedeflerine ulaşabilecektir (Öktem, 1993; Örücü vd., 2007, p. 220). Fakat zamanın doğru bir şekilde yönetilememesi işletmelerin iyi işleyememesine, zaman kaybının ve verimsiz çalışmaların yükselmesine, çalışma ortamının rahatsız edici olmasına, işletmelerin gelişim gösterememesine, maliyetin yükselmesine ve müşterileri memnuniyetinin düşerek, müşterilerin azalmasına neden olmaktadir (Güner, 2008, p. 163).

Zaman yönetimi esnasında karşılaşılabilecek sorunların ortaya konulması bir diğer önemli noktadır. Ortaya çıkacak sorunlar zamanı doğru kullanmayı engellemektedir ve bu sorunlar "zaman tuzakları" olarak ifade edilmektedir. Zaman tuzakları kişilerden, yönetim tarzından, işletme yapısından ve politik du- 
rumlardan kaynaklı oluşmaktadır. Bu tuzaklara örnek verecek olursak "gereksiz iş toplantıları, düzensiz çalışma, zamanı planlamamak, bilgisi eksik personel ile çalışmak, birçok işle ilgilenmek ve bunları bitirememek, gereksiz ziyaretçilerle görüşmek, sık seyahatler, her işi kişinin kendisinin yapmaya çalışması, yetki devri yapmaması, uygunsuz iş ortamları" gibi sayısı artırılabilecek olan birçok örnek vardır. İfade edilen zaman tuzakları zamanı kullanmada engellere ve kesintilere sebep olmaktadır(Yılmaz vd., 2018, p. 442).

Kişiler gerek iş ortamlarında gerekse hayatlarında birden fazla iş yapmaları gerektiği için zaman yönetimi, sadece çalışma yaşantılarında değil bütün yaşamın "verimli ve etkin" kullanılmasında önemli bir rolü üstlenmektedir (Boduç, 2016, p. 6). Ama zaman yönetiminde başarı sağlamanın gün içerisinde son anlara kadar ya da bitkin düşene kadar çalışmayla ilgisi yoktur. Kişinin çok meşgul olması, aceleci hareket etmesi veya bütün işlere dahil olmak istemesi profesyonel bir iş yapıldığının kanıtı değildir. Planlı bir şekilde hareket edilen günün kazancı, son ana kadar yapılan çalışmadan daha fazladır (Deniz, 2018, p. 20).

Zaman yönetimi, artan bilgi, eğitim veya kasıtlı olarak yapilan uygulama yoluyla edinilebilecek bir dizi alışkanlık veya öğrenilebilir bir davranıştır (Nadinloyi vd., 2013, p. 135). Bu davranışı etkin olarak yönetmek için "plan yapma, ziyaretçi trafiğini düzenleme, iletişim araçlarının etkili kullanma, yetki devri, önceliklerin belirlenmesi, ara boşlukların değerlendirilmesi, hayır demeyi öğrenme, oyalanmaya son verme, düzenli olma" gibi faaliyetler yapılmalıdır (Ökdem, 2019 , p. 81). Kelly (2002) ise zamanı etkin kullanmak adına bazı unsurları ele alan bir çerçeve çizmiştir. Bu çerçeve üç temel varsayıma dayanmaktadır. Bunlar; bireyler zamanın farkında olmalı, bireyler zaman alan faaliyetlerin farkında olmalı, bireylerin görev içi çalışma alışkanlıklarının pozitif olması şeklinde ifade edilmektedir. Zamanı etkin bir şekilde yönetmenin yararları ise; zamanın dar olmasından kaynaklanan stresi engellemek, bireysel verimliliği ve performansı artırmak, kurumun faaliyetlerindeki verimliliğin ve karlılığın artırılmasını sağlamak, kurum içinde karışıklığı engelleyerek zaman israfını önlemek, iş yetiştirememe ya da geciktirme gibi kişileri stres altında koyacak durumları engellemek ve kişilerin hem kendilerine hem de çevrelerine zaman ayırmalarını sağlamak şeklinde sıralanabilir (Aydeniz, 2000; Demirtaş ve Özer, 2007).

\section{METODOLOJI}

\subsection{Araștırmanın Amacı ve Modeli}

Bu araştırma da amaç; Konya'da görev yapan bir vakıf üniversitesindeki araştırma görevlilerin cinsiyetlerine göre zaman yönetimi tutumlarında bir farklılık olup olmadığının tespit edilmesidir. Araştırmanın vakıf üniversitesinde görev yapan araştırma görevlileri üze- rinde yapılmasının başlıca nedenleri arasında zamanı yönetmenin akademi alanında oldukça önemli olması ve vakıf üniversitesinde iş yoğunluğunun daha fazla olduğu düşünülmesidir. Araştırma da "ilişkisel tarama modeli" kullanılmıştır. "İlişkisel tarama modelinde çalışmalarda yer alan iki veya daha fazla sayıdaki değişken arasındaki ilişki ortaya çıkarılmaya çalışılmaktadır" (Gürbüz ve Şahin, 2018). Bu doğrultuda ilişkisel tarama modeline uygun şekilde yol izlenilerek var olan durumu ortaya çıkarabilmek için çalışılmaktadır ve bu çalışmayı yapabilmek adına aşağıdaki hipotezler geliştirilmiştir.

H1: Zaman yönetimi tutumları, cinsiyete göre anlamlı bir farklılık göstermektedir.

H1a: Zaman tuzakları, cinsiyete göre anlamlı bir farklılık göstermektedir.

H1b: Zamanı etkin kullanma yöntemleri, cinsiyete göre anlamlı bir farklılık göstermektedir.

\subsection{Veri Toplama Araçları ve Örneklem}

Araştırma grubuna anket uygulanacak olup anketin ilk kısmında katılımcıların cinsiyet, yaş, medeni hal, eğitim düzeyleri, işletmedeki hizmet sürelerinin belirlenmesi amacıyla araştırmacılar tarafından oluşturulan " 5 " soruluk demografik bilgi formu bulunmaktadır. İkinci kısımda, Ardıç (2010) tarafından yüksek lisans tezinde kullanılan ve yapılan anket çalışması ile geçerliliği ve güvenirliği onaylanmış 30 soruluk "zaman yönetimi” ölçeğinden faydalanılmıştır. Ölçeğin ilk 17 sorusu zaman tuzakları boyutu ile ilgiliyken, diğer 13 soru zamanı etkin kullanma yöntemleri ile ilgilidir. Ölçek 5'li “Likert” sistemine göre uyarlanmış ve sistemdeki ifadeler " $1=$ Kesinlikle katılmiyorum", "2= Katılmiyorum”, “3= Ne katılıyorum ne katılmıyorum", "4= Katıliyorum", "5= Kesinlikle katılıyorum" şeklinde tanımlanmıştır.

\subsection{Evren ve Örneklem}

Araştırmanın evreni bir vakıf üniversitesinin araştırma görevlilerinden oluşmaktadır. Toplam çalışan sayısı 90 kişiden oluşmaktadır. 4 kişi izinli olduğundan dolayı 86 kişiye anket uygulanarak veriler toplanmış ve analizler yapılmıştır.

\subsection{Araştırmanın Sınırlılıkları}

Araştırma çerçevesinde bazı sınırlılıklar bulunmaktadır. Bu sınırlılıklar; araştırma evreninin Konya'da izin alınabilen tek bir vakıf üniversitesi ili ile sınırlı olması, farklı ölçekler ile yapılacak çalışmalarda farklı sonuçlara ulaşılabilir olması, veri toplama aracının sınırlılıklarının olması şeklinde ifade edilebilir.

\subsection{Veri Analizi ve Bulgular}

Araştırmada istatistiksel analizler "SPSS for Windows 
23,0" programı vasıtasıyla gerçekleştirilmiştir. Güvenirliği tespit etmek için "Cronbach' s Alpha" testi, toplanan verilerin normal dağılım gösterip göstermediğini tespit etmek için normallik testi, birbirleri ile bağımlı olmayan değişkenleri belirlemek amacıyla Keşfedici Faktör Analizi, cinsiyete göre farklılık olup olmadığını tespit edebilmek için ise "T Testi" yapılmiştır

\subsubsection{Demografik Bulgular}

Yapılan anket çalışmasına cevap verenlerin \%51,2'sinin kadın, \%55,8'inin evli, \%77,9'unun 25-34 yaş arası, $\% 72,1$ yüksek lisans yaptığı, \%41,9'unun 1-3 yıl arası çalışanlar olduğu belirlenmiştir.

Tablo 1: Demografik Bilgiler

\begin{tabular}{|c|c|c|c|c|}
\hline & & & Frekans & Oran (\%) \\
\hline \multirow{4}{*}{ Cinsiyet } & Erkek & & 42 & 48,8 \\
\hline & Kadın & & 44 & 51,2 \\
\hline & Cevapsiz & & 0 & 0 \\
\hline & & Toplam & 86 & 100,0 \\
\hline \multirow{4}{*}{$\begin{array}{l}\text { Medeni } \\
\text { Durum }\end{array}$} & Evli & & 48 & 55,8 \\
\hline & Bekar & & 38 & 44,2 \\
\hline & Cevapsiz & & 0 & 0 \\
\hline & & Toplam & 86 & 100,0 \\
\hline \multirow{7}{*}{ Yaş } & 18 yaş altı & & 2 & 4 \\
\hline & $18-24$ & & 71 & 14,6 \\
\hline & $25-34$ & & 163 & 33,6 \\
\hline & $35-49$ & & 212 & 43,7 \\
\hline & $50-65$ & & 34 & 7,0 \\
\hline & Cevapsiz & & 2 &, 4 \\
\hline & & Toplam & 485 & 100,0 \\
\hline \multirow{10}{*}{$\begin{array}{l}\text { Eğitim } \\
\text { Durumu }\end{array}$} & İlkokul & & 103 & 21,2 \\
\hline & Ortaokul & & 93 & 19,2 \\
\hline & Lise & & 122 & 25,2 \\
\hline & Meslek Lisesi & & 23 & 4,7 \\
\hline & Ön lisans & & 36 & 7,4 \\
\hline & Lisans & & 92 & 19,0 \\
\hline & Yüksek Lisans & & 16 & 3,3 \\
\hline & Doktora & & 0 & 0 \\
\hline & Cevapsiz & & 0 & 0 \\
\hline & & Toplam & 485 & 100,0 \\
\hline \multirow{8}{*}{$\begin{array}{l}\text { Mevcut } \\
\text { İșletmede } \\
\text { Çalışma } \\
\text { Süresi }\end{array}$} & 1 ylldan az & & 71 & 14,6 \\
\hline & $1-3$ yil & & 103 & 21,2 \\
\hline & 4-6 yil & & 111 & 22,9 \\
\hline & 7-9 yll & & 57 & 11,8 \\
\hline & $10-15 \mathrm{yll}$ & & 58 & 12,0 \\
\hline & $16-20 \mathrm{y} 1 \mathrm{l}$ & & 40 & 8,2 \\
\hline & 20 yıl üzeri & & 45 & 9,3 \\
\hline & Cevapsiz & Toplam & $\begin{array}{l}1 \\
485\end{array}$ & $\begin{array}{l}0,2 \\
100,0\end{array}$ \\
\hline
\end{tabular}




\subsubsection{Normallik Analizi}

Hipotezleri sınamaya geçmeden önce hangi analizlerin yapılmasının uygun olduğunu tespit edebilmek için normallik testi yapılmıştır. Tablo 2'de yer alan test sonucunda her bir maddenin Skewness ve Kurtosis değerlerinin "-2 ve 2" değerleri arasında olduğu görülmüştür. Bu değerler George vd. (2010)’a normal da- ğılım için yeterli seviyelerdir. Tüm bunların ışığında bu çalışmada da ifadelerin normal dağılım gösterdiği düşünülerek gerekli analizler yapılmıştır.

Tablo 2: Normallik Analizi

\begin{tabular}{|c|c|c|c|c|}
\hline Zaman Yönetimi & 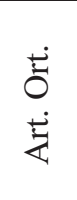 & 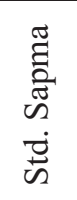 & $\frac{\infty}{\infty}$ & 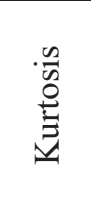 \\
\hline 1. Ziyaretçiler sebebi ile günlük çalışmalarım aksar. & 3,31 & 1,15 &,- 266 &,- 862 \\
\hline 2. Çoğunlukla mesai saatlerinde yapmam gereken işler mesai dışına taşar & 3,05 & 1,21 &,- 317 &,- 990 \\
\hline 3. Mesai içinde çalışma zamanımın çoğu plan dışı olaylara göre harcanıyor. & 2,89 & 1,07 & ,271 &,- 640 \\
\hline $\begin{array}{l}\text { 4. Örgütte çalışan diğer personelin yapması gereken işleri yapmak zorunda } \\
\text { kalırım. }\end{array}$ & 3,01 & 1,18 & ,021 &,- 875 \\
\hline 5. İş arkadaşlarımın görüşme isteklerinden dolayı çalışmalarım bölünür. & 3,54 & 108 &,- 838 & ,215 \\
\hline 6. Çalışmaları, telefon görüşmeleriyle sık sık kesilir. & 3,51 & 1,03 &,- 388 &,- 864 \\
\hline 7. Genellikle önemli işlerimi ertelemek zorunda kalırım. & 3,61 & ,99 &,- 330 &,- 607 \\
\hline 8. Toplantılar nedeni ile çalışmalarımda aksaklıklar olur. & 3,44 & 1,01 &,- 220 &,- 564 \\
\hline 9. Ziyaretlerim için belirli zaman dilimi ayırabilirim. & 3,39 & ,94 &,- 537 &,- 053 \\
\hline 10. Çalışma hayatımda birkaç işi birden yaparım. & 3,84 & ,91 &,- 922 &, 649 \\
\hline $\begin{array}{l}\text { 11. Herhangi birinin yardım isteğini işlerimin aksatması nedeni ile geri } \\
\text { çeviririm. }\end{array}$ & 2,09 & 1,10 & ,946 &, 172 \\
\hline 12. Çalışma hayatımda yetki devrinde bulunurum. & 2,64 & 1,07 &, 125 &,- 690 \\
\hline 13. Gün sonunda planlarımın ne ölçüde gerçekleştiğini bilirim. & 3,93 & ,87 & $-1,205$ & 1,564 \\
\hline 14. Rutin işlerle ilgili verimli olarak planlama yaparım. & 3,72 &, 87 &,- 920 & 1,159 \\
\hline $\begin{array}{l}\text { 15. Planlama yapmadan önce ulaşmak istediğim hedefi net bir şekilde } \\
\text { belirlerim. }\end{array}$ & 3,97 & ,92 & $-1,160$ & 1627 \\
\hline 16.. Günlük çalışmalarımı yazılı bir plan dahilinde yaparım. & 3,03 & 1,25 &, 007 & $-1,064$ \\
\hline 17. Sorunlar çıkmadan önce önleyici tedbirler alırım. & 3,62 & ,85 &,- 931 & 1,645 \\
\hline 18. Masam tertipli ve düzenlidir. & 3,53 & 1,26 &,- 674 &,- 397 \\
\hline 19. Günlük çalışma planında yer alan aktiviteleri zamanında bitiririm. & 3,43 &, 87 &,- 606 &, 745 \\
\hline 20. Her şeyi yerine koyar, aradığımı zamanında bulurum. & 3,88 & ,95 &,- 688 &, 057 \\
\hline 21. Mesai içerisinde yapılacaklar arasında öncelikli olanları belirlerim. & 4,15 & ,87 & $-1,490$ & 1,879 \\
\hline 22. Günlük planlarımı yazılı yapmak yerine zihnimde tasarlarım. & 3,39 & ,94 &,- 504 &,- 671 \\
\hline 23. Bazı işleri ertelemem diğer işlerimin de aksamasına neden olur. & 2,81 & 1,01 & ,246 &,- 609 \\
\hline 24. Çalışma esnasında işim harici internette çok vakit harcarım. & 3,65 & 1,09 &,- 868 &, 194 \\
\hline 25.Çalışanlar arasında iletişim eksikliği olduğunu düşünüyorum. & 2,51 & 1,07 & ,499 &,- 336 \\
\hline 26. İşime ve toplantılarıma zamanında gelirim. & 4,41 & 0,70 & $-1,182$ & 1,538 \\
\hline 27. Fiziki çalışma ortamım (1şıklandırma, ses, görüntü vb.) oldukça & 3,66 & 1,05 &,- 928 &, 510 \\
\hline $\begin{array}{l}\text { rahattır. } \\
28 \text { Her isi hir kere ele all }\end{array}$ & 2,75 & ,93 &,- 024 &,- 657 \\
\hline 28. Her iş1 bir Kere ele alırm. & 4,32 &, 77 & $-1,266$ & 1,755 \\
\hline 30. Belirli bir zamanda belirli bir işi bitiririm. & 4,22 & ,69 &,- 977 & 1,969 \\
\hline
\end{tabular}




\subsubsection{Keşfedici Faktör Analizi}

Zaman yönetimi ölçeğinin boyutlarını incelemek ve boyutlar arası ilişkide tek boyutluluğu sağlamak için keşfedici faktör analizi yapılmıştır (Tablo 3). Keşfedici faktör analizinde örneklem sayısının uygunluğunu ifade eden Kaiser-Meyer-Olkin (KMO) değerinin ,718 olarak tespit edildiği ve kabul edilebilir düzeyde olduğu görülmüştür (Gürbüz ve Şahin, 2018). Zaman yönetimi yapısına yönelik faktör analizinin uygulanabileceğini belirledikten sonra "Direct Oblimin" dik döndürme yöntemini esas alan temel eksenler faktör analizi yapılmıştır. Hair vd. (2014) tavsiye ettiği gibi faktör yükü 0,40 veya daha yüksek olanlar analize dahil edilmiştir. Bu şartı sağlamayan
7.,11.,16.,17.,19.,26.,27., ve 30. maddeler çıkartılmış ve analiz tekrar yapıldığında tüm faktör yüklerinin 0,40 üzerinde olduğu görülmüştür.

Bileşenler; zaman tuzakları ve zamanı etkin kullanma şeklinde adlandırılmıştır. Zaman Yönetimi boyutlarının öz değer, açılanan varyans ve güvenirlik $(\alpha)$ katsayıları Tablo 3'de görülmektedir. Boyutların 1 'in üzerinde öz değere sahip olup toplam varyansın $\% 51,22$ 'sini temsil etmektedir. Her bir boyutun $\alpha$ değerlerinin 0,70'den yüksek olduğu ve güvenilirliğin sağlandığı görülmüştür. Açıklayıcı (keşfedici) faktör analizinin önerdiği boyutlar için bileşik değerli değişkenler üretilmiş ve sonraki analizlerde bu bileşik değerler göz önüne alınmıştır.

Tablo 3: Zaman Yönetimi Ölçeği Keşfedici Faktör Analizi (n=86)

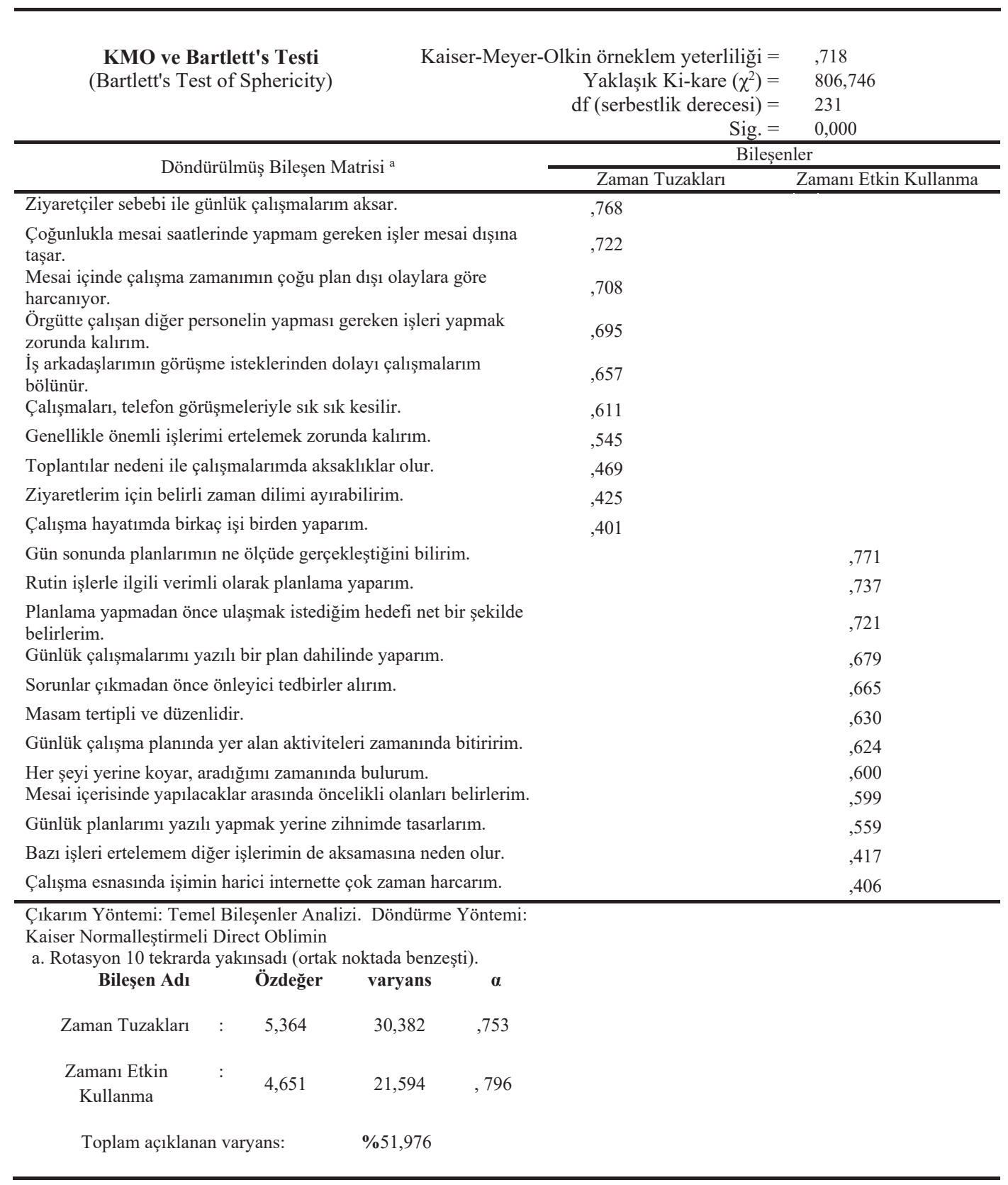


Tablo 4: Cronbach's Alpha Analizi

\begin{tabular}{lcc}
\hline Zaman Tuzakları & $\begin{array}{c}\text { Cronback's } \\
\text { Alpha }\end{array}$ & $\begin{array}{c}\text { Soru } \\
\text { Sayıs }\end{array}$ \\
\hline Zamanı Etkin Kullanma &, 753 & 10 \\
\hline Zaman Yönetimi &, 796 & 12 \\
\hline
\end{tabular}

Tablo 5: T-Testi Analizi

\begin{tabular}{|c|c|c|c|c|c|c|}
\hline Değișken & Grup & $\mathbf{N}$ & Ort. & Std. Sap. & $\mathbf{T}$ & Sig. \\
\hline & Kadın & 44 & 3,7345 & 63558 & $-2,041$ & , 124 \\
\hline $\begin{array}{c}\text { Zaman } \\
\text { Tuzakları }\end{array}$ & Erkek & 42 & 3,4981 & ,41118 & & \\
\hline
\end{tabular}

Tablo 6: T-Testi Analizi

\begin{tabular}{|c|c|c|c|c|c|c|}
\hline Değişken & Grup & $\mathbf{N}$ & Ort. & Std. Sap. & $\mathbf{T}$ & Sig. \\
\hline & Kadın & 44 & 3,4405 &, 61170 & 1,048 &, 047 \\
\hline $\begin{array}{c}\text { Zamanı Etkin } \\
\text { Kullanma }\end{array}$ & Erkek & 42 & 3,3023 & 60415 & & \\
\hline
\end{tabular}

\subsubsection{Araştırma Ölçeklerinin Geçerliliği ve Güveni- lirliği}

T-testi neticesinde zamanı etkin kullanmanın $\mathrm{T}$ (86):1,048, p<0.05 cinsiyet gruplarına göre anlamlı bir biçimde farklılaştığı gözlenmiştir. Kadınların, zamanı etkin kullanmalarına yönelik algıları (x:3,4405), erkeklerin zamanı etkin kullanmalarına yönelik algılarına göre daha yüksektir.

Tablo 4'te görüldüğü üzere, araştırmada kullanılan ölçeklerin güvenilirlik katsayılarının 0.70 'in üzerinde olduğu tespit edilmiştir. Yani kullanılan ölçeklerin “Cronbach' s Alpha" değerinin yüksek olduğu görülmektedir (İslamoğlu ve Alnıaçık, 2014, p. 292).

\section{Fark Testleri (T-Testi)}

Araştırmanın bu kısmında zaman yönetiminin cinsiyete göre anlamlı bir farklılık sergileyip sergilemediği T-Testi ile incelenmiştir.

Yapılan T-testi neticesinde zaman tuzakları ile cinsiyet arasında anlamlı bir farklılık olmadığı görülmüştür $(\mathrm{p}>0,05)$

T-testi neticesinde zamanı etkin kullanmanın $\mathrm{T}$ (86):1,048, $\mathrm{p}<0.05$ cinsiyet gruplarına göre anlamlı bir biçimde farklılaştığı gözlenmiştir. Kadınların, zamanı etkin kullanmalarına yönelik algıları (x:3,4405), erkeklerin zamanı etkin kullanmalarına yönelik algılarına göre daha yüksektir.

\section{SONUÇ VE ÖNERILLER}

Bu araştırmada bir vakıf üniversitesinde görev yapan araştırma görevlilerinin cinsiyetlerine göre zaman yönetimi tutumları arasında anlamlı bir farklılık görülüp görülmediği toplanan anketler vasıtasıyla analiz edilerek belirlenmeye çalışılmıştır.

Yapılan t-testi sonuçlarına göre zaman tuzaklarının, cinsiyet değişkenine göre anlamlı bir farklılık göstermediği tespit edilmiştir. Bu sonuçlar doğrultusunda "H0: Zaman tuzakları, cinsiyete göre anlamlı bir farklılık göstermemektedir" hipotezi desteklenmektedir. Zaman tuzaklarının cinsiyete göre değişmediği sonucu, Çimen (2017), Alay ve Koçak (2003), Çağlıyan ve Güral (2009) tarafından yapılan çalışmaların sonuçları ile desteklenmektedir. Zamanı etkin kullanma yöntemleri ise yapılan t-testi sonuçlarına göre cinsiyet değişkenine göre anlamlı bir farklılık göstermektedir. Bu sonuçlar doğrultusunda kadınların zamanı etkin kullanma düzeyleri erkeklere göre daha yüksek olduğu tespit edilmiştir ve H1b: "Zamanı etkin kullanma yöntemleri, cinsiyete göre anlamlı bir farklılık göstermektedir" hipotezi desteklenmektedir. Zamanı etkin kullanma yöntemlerinin cinsiyete göre değiştiği sonucu, Tektaş ve Tektaş (2010), Alay ve Koçak (2003), Demirtaş ve Özer (2007) tarafından yapılan çalışmaların sonuçları ile desteklenmektedir.

Gerek zaman tuzakları gerekse zamanı etkin kullanma yöntemlerinde özellikle erkek araştırma görevlilerinin, kadın araştırma görevlilerine göre zamanı etkin kullanmak için daha çok çaba göstermeleri gerek- 
mektedir. Bunun için öncelikler belirlenip planlama yapılabilir, ziyaretçiler için ziyaret saati ayarlanabilir, iletişim araçları daha etkin kullanılabilir ve hayır denilmesi gereken yerlerde hayır denilmelidir.

\section{KAYNAKÇA}

AKATAY, A. (2003). Örgütlerde Zaman Yönetimi. Selçuk Üniversitesi Sosyal Bilimler Enstitüsü Dergisi(10), 281-300.

AKYÜZ, B., ÜNAL, Ö. F., MEHMET, M., \& DOGER, F. (2015). İnşaat Sektöründe Zaman Yönetimi: Irak'in Küzeyindeki Türk Şantiyeleri Üzerine Bir Araştirma. Süleyman Demirel Üniversitesi Sosyal Bilimler Enstitüsü Dergisi(21),

ALAY, S., \& KOÇAK, S. (2003). Üniversite Öğrencilerinin Zaman Yönetimleri ile Akademik Başarilari Arasindaki İlişki. Kuram ve Uygulamada Eğitim Yönetimi, 35(35), 326-335.

ALBAYATI, N. H. H. (2018). Zaman Yönetiminin İs Tatmini Ve Tükenmişlik Üzerindeki Etkisi: Akademisyenler Üzerine Bir Araştirma. Selçuk Üniversitesi Sosyal Bilimler Enstitüsü İşletme Anabilim Dali Yönetim Ve Organizasyon Bilim Dali Yayınlan

ARDIÇ, C. (2010). Zaman Yönetimi Ve Zaman Yönetiminde Dönüștürücü Liderlerin Davranıșlarını Belirlemeye Yönelik Bir Araştırma. Gazi Üniversitesi, Sosyal Bilimler Enstitüsü, Yayınlanmamış Yüksek Lisans Tezi.

AYDENIZ, N. (2000). Zaman Yönetimi Açısından Diyarbakır Kamu Ve Özel Sektöründe Verimli Ve Etkin Zaman Kullanımı Araştırması. Yönetim ve Ekonomi: Celal Bayar Üniversitesi Iktisadi ve İdari Bilimler Fakültesi Dergisi, 6(1), 45-70.

BODUÇ, N. (2016). Hemşirelerde Zaman Yönetimi. Hemşirelikte Yönetim Anabilim Dali Hemşirelikte Yönetim Programi Yönetim Bilim Dalı Yayınlanmamıș Yüksek Lisa

CLAESSENS, B. J., VAN EERDE, W., RUTTE, C. G., \& ROE, R. A. (2007). A Review Of The Time Management Literature. Personnel review, 36(2), 255-276.

ÇAĞLIYAN, V., \& GÜRAl, R. (2009). Zaman Yönetimi Becerileri: Meslek Yüksekokulu Öğrencileri Üzerine Bir Değerlendirme. KMU IIIBF Dergisi.

ÇELIK, A., ȘIMŞEK, M. Ș., \& SOYSAL, A. (2016). Zaman Yönetimi ve Yönetsel Zamanda Etkinlik. Eğitim Yayınevi, Konya.

ÇIMEN, K. (2017). Ünİversİte Öğretİm Elemanlarinin Zaman Yönetİmİ Anlayişlarinin İncelenmesİ. Sportif Bakış: Spor ve Eğitim Bilimleri Dergisi, 4(2), 111-118.

DEMIRTAŞ, H., \& ÖZER, N. (2007). Öğretmen adaylarının zaman yönetimi becerileri ile akademik başarısı arasındaki ilişkisi. Eğitimde Politika Analizleri ve Stratejik Araştırmalar Dergisi, 2(1), 3447.

DENIZ, M. O. (2018). Bİr Vakif Üniversitesinde Çalişan Akademik Ve İdari Personelin Zaman Yönetimin İlişkin Tutumlarinin İncelenmesi: Fatih Sultan Mehmet Vakif Üniversitesi. Trakya Üniversitesi Sosyal Bilimler Enstitüsü Rekreasyon Yönetimi Anabilim Dali
Yüksek Lisans Tezi Yayınlanmamış Yüksek Lisans Tezi

DÖNER, H. (2016). Hastane Yöneticilerinin Zaman Yönetimi Tekniklerinin İncelenmesi Namik Kemal Üniversitesi Sosyal Bilimler Enstitüsü Sağlik Yönetimi Anabilim Dali Yayımlanmamış Yüksek Lisans

ERDEM, R., PIRINÇCI, E., \& DIKMETAS, E. (2005). Üniversite öğrencilerinin zaman yönetimi davranışları ve bu davranışların akademik başarı ile ilişkisi. Manas Üniversitesi Sosyal Bilimler Dergisi, 14(7), 167-177.

ERIȘ, H., ILIMAN, E., \& ÖZMEN, S. (2017). Zaman Yönetimi Ve Akademik Başarı Değerlendirmesi: Sağlık Hizmetleri Meslek Yüksekokulu Öğrencileri. IVth International Eurasian Educational Research Congress Bildiri Özetleri Kitabi.

GREENE, R., ELFFERS, J., \& BABAYIĞIT, Z. İ. (2004). İktidar: güç sahibi olmanın 48 yasası: Altın Kitaplar.

GÜÇLÜ, N. (2001). Zaman Yönetimi. Kuram ve Uygulamada Eğitim Yönetimi, 25(25), 87-106.

GÜNER, M. (2008). Konfeksiyon İșletmelerinde Örgütsel Zaman Yönetimi İçin Abc Anali Uygulanmasi. Journal of Textile \& Apparel/Tekstil ve Konfeksiyon, 19(2).

GÜRBÜZ, \& ŞAHIN, F. (2018). Sosyal Bilimlerde Araştırma Yöntemleri Felsefe - Yöntem - Analiz: Seçkin Yayıncılık.

GÜRBÜZ, M., \& AYDIN, A. H. (2012). Zaman Kavramı Ve Yönetimi. Kahramanmaraş Sütçü İmam Üniversitesi Sosyal Bilimler Dergisi, 9(2), 1-20.

İSLAMOĞLU, A. H., \& Alnıaçı, Ü. (2014). Sosyal Bilimlerde Araştirma Yöntemleri. Beta Yayınevi(3463), 511.

KELLY, W. E. (2002). Harnessing The River Of Time: A Theoretical Framework Of Time Use Efficiency With Suggestions For Counselors. Journal of Employment Counseling, 39(1), 12-21.

KIBAR, B. (2014). Karabük Üniversitesi Öğrencilerinin Zaman Yönetimi Becerileri İle Akademik Başarıları Arasındaki İlişki. Yayımlanmamış Yüksek Lisans Tezi, Karabük Üniversitesi Sosyal Bilimler Enstitüsü Kamu Yönetimi Anabilim Dalı, Karabük.

KIBAR, B., Fidan, Y., \& Yıldıran, C. (2014). Öğrencilerin Zaman Yönetimi Becerileri İle Akademik Başarilari Arasindaki İlişki: Karabük Üniversitesi. Business \& Management Studies: An International Journal, 2(2), 136-153.

KIDAK, L. B. (2011). Hastane Yöneticilerinin Zaman Yönetimi Tutumlarının Belirlenmesi: Izmir Ili Eğitim Ve Araştırma Hastaneleri Uygulaması. Selçuk Üniversitesi Sosyal Bilimler Enstitüsü Dergisi, 25, 159-172.

KOCH, R. (2011). The 80/20 Principle: The Secret of Achieving More with Less: Updated 20th anniversary edition of the productivity and business classic: Hachette UK.

NADINLOYI, K. B., HAJLOO, N., GARAMALEKI, N. S., \& SADEGHI, H. (2013). The Study Efficacy Of Time Management Training On Increase Academic Time Management Of Students. Procedia-Social and Behavioral Sciences, 84, 134-138.

ÖKDEM, M. (2019). Üniversitesi Öğrencilerinin Zaman Yönetiminde Düștükleri Zaman Tuzaklari Ve Bunlarla Bașetme 
Türkiye Sosyal Araştırmalar Dergisi, 23(2), 79-94.

ÖKTEM, M. K. (1993). Zaman yönetimi: Örgütsel etkililiği arttırmada zaman faktöründen yararlanılması. Amme İdaresi Dergisi, 26(1), 217-237

ÖREN, K. (2016). İşletmelerde Verimlilik Ve Performansin Arttirilmasinda Zaman Yönetimi. Hak İş Uluslararası Emek ve Toplum Dergisi, 5(11), 186-

ÖRÜCÜ, E., KANBUR, M. T., TİKİCİ, M., \& Kanbur, A. (2007) Farkli Sektörlerde Faaliyetlerini Sürdüren İşletmelerde Zaman Yönetimi Üzerine Ampi Araştirma: Bursa İli Örneği Elektronik Sosyal Bilimler Dergisi, 6(20), 9-31.

ÖZER, M. A. (2012). Çalişma Hayatinda Zaman Tuzaklari Ve Zamani Etkİn Yönetmek. Hak Işs Uluslararası Emek ve Toplum Dergisi, 1(2), 44-75.

SEZEN, A. (2013). İlahiyat Fakültesi Öğrencilerinin Zaman Yönetimi Becerilerinin Incelenmesi. Akademik Bakış Dergisi, 38, 1-18.

SILAHTAROĞLU, F. (2004). Akademisyenlerde Zaman Yönetimi", Yüksek Lisans Tezi, Gaziosmanpaşa Üniversitesi Sosyal Bilimler Enstitüsü, Tokat

SMITH. (1998). Hayatı ve Zamanı Yönetmenin On Dogal Yasası, İstanbul: Sistem Yayınc1lık.

SMITH, H. (1998). Hayatı ve Zamanı Yönetmenin 10 Doğal Yasası (Çev, Adalet Çelbiş). İstanbul, Sistem Yayıncılık.

SPSS for Windows Step by Step: A Simple Guide and Reference, 17.0 update (10a ed.) Boston: Pearson

TEKTAŞ, M., \& TEKTAŞ, N. (2010). Meslek yüksekokulu öğrencilerinin zaman yönetimi ve akademik başarıları arasındaki ilișki. Selçuk Üniversitesi Sosyal Bilimler Enstitüsü Dergisi(23), 221-229.

TENGILIMOĞLU, D., \& BEKTAŞ, A. (2012). İşletme Yönetimi: Seçkİn Yayin

TÜRKEL, S., \& LEBLEBICI, D. N. (2000). Yönetim Bilimi Açisindan Zamanin Anlami ve Etkili Zaman Yönetiminin Esaslari. Hacettepe Üniversitesi İktisadi Ve İdari Bilimler Fakültesi 18(1), 351-376.

ULUSOY, İ. T. (1995). Zaman Yönetimi Ve Yönetici Açlsından Zaman Yönetiminin Araştırılması. İstanbul Üniversitesi SosyalBilimler Enstitüsü İşletme Fakültesi Organizasyon ve İşletme Politikası Doktora Programı Yayımlanmamış Doktora Tezi,

YILMAZ, A., DIKEN, A., KOÇYIĞIT, N., \& ÖZER TOPALOĞLU, E. (2018). İşletmelerde Zaman Yönetimi: Perakendecilik Sektöründe Bir Uygulama. Sosyal Bilimler Dergisi / The Journal Of Social Science, 5(28), 439 